\title{
Continuous planting under a high density enhances the competition for nutrients among young Cunninghamia lanceolata saplings
}

\author{
Tingfa Dong ${ }^{1}$ - Yunxiang Zhang ${ }^{1} \cdot$ Yuanbin Zhang ${ }^{1} \cdot$ Sheng Zhang ${ }^{1}$
}

Received: 28 April 2015 / Accepted: 4 September 2015 /Published online: 16 September 2015

(C) INRA and Springer-Verlag France 2015

\begin{abstract}
- Key message A high-density plantation inhibited growth and biomass accumulation of Cunninghamia lanceolata (Lamb.) Hook. saplings, as well as their photosynthesis. This inhibition was enhanced in a soil that had been previously planted with the same species. The main factors limiting photosynthesis and growth were leaf-level irradiance and nutrient availability, mainly of $P$ and $M g$.

- Context The planting density and continuous planting greatly affect the photosynthesis and productivity of Chinese fir plantations. The effects of high density and of continuous plantations over several revolutions need be disentangled.

- Aims In this study, the responses of $C$. lanceolata seedlings to a high planting density were tested. Two soils were compared: a soil from a secondary forest and one from a continuous Chinese fir plantation. The study focused on growth and the potential processes involved in deduced photosynthesis.

- Methods C. lanceolata seedlings were planted in wooden boxes $(100 \times 100 \times 50 \mathrm{~cm})$ with high and low planting densities (16 vs 1 plant $\mathrm{m}^{-2}$ ) in two types of soil.

- Results Under the high planting density, C. lanceolata showed less growth and biomass accumulation at the individual level and lower photosynthetic rate and instantaneous photosynthetic nutrient use efficiency (PNUE and PPUE) at the leaf level. These negative effects were larger in soils that have been continuously planted with Chinese fir. The low
\end{abstract}

Handling Editor: Erwin Dreyer

Sheng Zhang

zhangsheng@imde.ac.cn

1 Key Laboratory of Mountain Surface Processes and Ecological Regulation, Institute of Mountain Hazards and Environment, Chinese Academy of Sciences, Chengdu 610041, China photosynthesis was related to low phosphorus and magnesium contents in the leaves, changes in the foliar N/P and chlorophyll a/b ratios, and the limitation of the mesophyll conductance.

- Conclusions The study showed that a high planting density induced enhanced competition for nutrients (particularly for $\mathrm{P}$ and $\mathrm{Mg}$ ) and that this competition is enhanced in soils from continuous plantations compared to soils from natural forests.

Keywords Chinese fir · Continuous planting · Planting density $\cdot$ Photosynthesis $\cdot$ Photosynthetic nutrient use efficiency

$\begin{array}{ll}\text { Abbreviations } \\ \Phi & \text { Apparent quantum efficiency } \\ \Gamma & \mathrm{CO}_{2} \text { compensation point } \\ A & \text { Net photosynthesis rate } \\ A_{\max } & \text { The light-saturated photosynthetic rate } \\ \text { Caro } & \text { Carotenoid } \\ \text { CE } & \text { Carboxylation efficiency } \\ \text { Chl } a & \text { Chlorophyll a } \\ \text { Chl } b & \text { Chlorophyll b } \\ C_{\mathrm{i}} & \text { Intercellular CO } 2 \text { concentration } \\ E & \text { Transpiration } \\ g_{\mathrm{m}} & \text { Mesophyll conductance } \\ g_{\mathrm{s}} & \text { Stomatal conductance } \\ J_{\mathrm{max}} & \text { The maximum rate of electron transport } \\ & \text { driving regeneration of RuBP } \\ L_{\mathrm{CP}} & \text { Light compensation point } \\ \text { PNUE } & \text { Photosynthetic nitrogen use efficiency } \\ \text { PPUE } & \text { Photosynthetic phosphorus use efficiency } \\ \text { Tchl } & \text { Total chlorophyll } \\ V_{\mathrm{cmax}} & \text { The maximum rate of RuBP carboxylation } \\ V_{\mathrm{TPU}} & \text { Triose-phosphate utilization }\end{array}$




\section{Introduction}

Cunninghamia lanceolata (Lamb.) Hook is an important coniferous, fast-growing species that has been widely planted over an area of approximately 12 million ha in southern China (FAO 2010), which comprises about one third of the country's total plantation area. In addition to the economic benefits (timber production), Chinese fir forests provide important ecological benefits, including carbon sequestration, soil erosion conservation, and groundwater reposition at regional and national scales (Tian et al. 2011). Recently, the plantation area of Chinese fir has been enlarged due to an increased demand for timber. However, the yield and productivity of pure Chinese fir plantations are extremely low because of low photosynthetic efficiency, poor soil fertility, and nonscientific management practices (Wang et al. 2010; Tian et al. 2011; Zhang and Wang 2012). Continuous planting on the same site is an important reason for the decline in soil fertility and the decreases in wood volume and productivity (Ding and Cheng 1995; Zhang et al. 2004; Tian et al. 2011). The production of toxic substances, nutrient deficiency, and understory competition may be responsible for the decline in yield in continuously planted sites (Ding and Cheng 1995; Bi et al. 2007; Chen and Wang 2013). Compared with soils that were continuously planted with Chinese fir, soils that were first planted had fewer toxic substances, lower nutrient losses, and less growth inhibition for $C$. lanceolata. However, studies of the physiological response of $C$. lanceolata to different soils are scarce.

Plant density greatly affects plantation productivity. A high planting density can reduce biomass production, decrease the photosynthetic efficiency, and change the resource use efficiency (Mediavilla et al. 2001; Wang et al. 2005; Dybzinski et al. 2013; Chen et al. 2014). Although these differences are species specific and vary with the developmental stage, a decrease in the photosynthetic rate frequently occurs in many plants, especially in saplings. Several factors are responsible for the changes in photosynthesis, such as the mineral nutrient content, chlorophyll content, mesophyll conductance to $\mathrm{CO}_{2}$, and the RuBP-regeneration-limited rates of electron transport in leaves (Flexas et al. 2008; Garrish et al. 2010; Chen et al. 2011). The factors that affect photosynthesis are sophisticated. For example, mineral nutrient deficiency may cause changes in the Rubisco or chlorophyll contents. Conversely, a decrease in the Rubisco content or activity for other reasons would very likely be reflected in leaf $\mathrm{N}$ contents or the N/P ratio. In addition to nutrients in the soils and leaves, light and water also strongly affect photosynthesis (Anten and Hirose 2001; Dorman et al. 2015). However, little is currently known about the process leading to a density-dependent decrease of photosynthesis in Chinese fir in soils from continuous plantations.

To better understand the consequences of the densitydependent responses of $C$. lanceolata, a controlled experiment was performed, and physiological and nutrient stoichiometric measurements were conducted. We will address the following questions: (1) Is growth of $C$. lanceolata inhibited more by high planting density in soils that have been continuously planted with Chinese fir than in soils that were first planted (secondary broadleaf forest soils)? (2) What is the mechanism underlying the low photosynthetic activity caused by a high planting density?

\section{Materials and methods}

\subsection{Plant materials and experimental design}

In this study, 1-year-old $C$. lanceolata seedlings were collected from two populations (Hongya and Huitong). The Hongya population was from the Hongya National Forest Farm located at $29^{\circ} 38^{\prime} \mathrm{N}$ and $102^{\circ} 58^{\prime} \mathrm{E}$. The mean annual rainfall at this site ranges from 2230 to $2550 \mathrm{~mm}$, the average annual temperature is $10.5{ }^{\circ} \mathrm{C}$, and the mean altitude is $750 \mathrm{~m}$. The Huitong population was from the Huitong National Research Station of Forest Ecosystems located at $26^{\circ} 50^{\prime} \mathrm{N}$ and $109^{\circ} 36^{\prime} \mathrm{E}$. The mean annual rainfall at this site ranges from 1200 to $1400 \mathrm{~mm}$, the average annual temperature is $16.5^{\circ} \mathrm{C}$, and the mean altitude is $400 \mathrm{~m}$. The two locations are the major natural distribution regions of $C$. lanceolata in southern China. Two types of soil were used in this study. The soils that were continuously planted with Chinese fir were collected from a 30-year-old Chinese fir plot. The soils that were first planted with Chinese fir were collected from a secondary broadleaf forest plot. Both plots were located at the Hongya National Forest Farm (soils were collected from a depth of 20-40 cm). The main nutrients in the two types of soil are listed in Table 1.

The experiment had a two factor random design, namely two types of soil $\times 2$ planting densities (high and low density). Each treatment included at least eight wooden boxes $(100-\mathrm{cm}$ length $\times 100$-cm width $\times 50$-cm height), with at least four boxes for each population. The seedlings in the "high-density" stands were arranged in a regular chessboard pattern, approximately equally spaced (arranged in rows of $4 \times 4$ individuals). Therefore, there were 16 C. lanceolata seedlings per box (one square meter). For the "low-density" treatment, one seedling was planted in each box. To obtain more low-density individuals, eight additional boxes (each low-density treatment added four boxes) were used. Therefore, there were total of 12 boxes for each low-density treatment. All seedlings were grown in a naturally lit greenhouse under ambient conditions with a daytime temperature of $19-28^{\circ} \mathrm{C}$, a nighttime temperature of 12 $18{ }^{\circ} \mathrm{C}$, and a relative humidity of $40-85 \%$ at the Chengdu Institute of Biology, the Chinese Academy of Sciences. The seedlings were watered every day and were grown for one growing season (from March to September). 
Table 1 The organic C, N, and P contents in the soils that were first (control) and continuously planted with Chinese fir (rotation)

\begin{tabular}{llll}
\hline Soils & Organic $\mathrm{C}\left(\mathrm{g} \mathrm{kg}^{-1}\right)$ & $\mathrm{N}\left(\mathrm{g} \mathrm{kg}^{-1}\right)$ & $\mathrm{P}\left(\mathrm{g} \mathrm{kg}^{-1}\right)$ \\
\hline Control & $35.55 \pm 2.46$ & $3.41 \pm 0.14$ & $0.44 \pm 0.02$ \\
Rotation & $24.01 \pm 1.18$ & $2.27 \pm 0.20$ & $0.25 \pm 0.02$ \\
$P$ value & 0.000 & 0.002 & 0.000 \\
\hline
\end{tabular}

The statistical significance was according to Student's $t$ test $(n=3)$

\subsection{Growth measurements}

Eight seedlings from each treatment (four seedlings for each population, the same as the measurements below) were selected from the center of each box and harvested at the end of the experiment. They were divided into individual needles, stems, and roots. Height growth measurements were based on the length of the stem from the collar to the apex, and the stem basal expansion was estimated from the stem diameter measured $3 \mathrm{~cm}$ above the collar using calipers.

\subsection{Gas exchange measurements and response curves}

Before harvest, eight seedlings were selected from each treatment for gas exchange measurements. The net photosynthetic rate $(A)$, stomatal conductance $\left(g_{\mathrm{s}}\right)$, and transpiration $(E)$ were measured using the LI-COR 6400 portable photosynthesis measuring system (LI-COR, Lincoln, NE, USA). Gas exchange measurements were taken between 08:00 and 11:30, and carbon dioxide gas cylinders (LI-COR) were used to provide a constant and stable $\mathrm{CO}_{2}$ concentration. Prior to measurement, samples were illuminated with saturating irradiance $\left(1000 \mu \mathrm{mol} \mathrm{m}{ }^{-2} \mathrm{~s}^{-1}\right.$ PPFD) provided by the LI-COR LED light source for $10 \mathrm{~min}$ to achieve full photosynthetic induction. A standard LI-COR leaf chamber $\left(2 \times 3 \mathrm{~cm}^{2}\right)$ was used. The parameters were as follows: leaf temperature, $25^{\circ} \mathrm{C}$; leaf-to-air vapor pressure deficit, $1.5 \pm$ $0.5 \mathrm{kPa}$; and $\mathrm{CO}_{2}$ concentration, $400 \pm 5 \mu \mathrm{mol} \mathrm{mol}{ }^{-1}$. Because the measured leaves did not fill the chamber $\left(2 \times 3 \mathrm{~cm}^{2}\right)$, the actual leaf areas were used to normalize the data. The leaves in the chamber were bordered and photographed (600 dpi), and leaf areas were calculated using a scanner (Canon Scanner 5600F, Chengdu, China) and imaging software (Image J, National Institutes of Health, MD, USA).

The response of $A$ to light was measured at 1800, 1600, 1400, 1200, 1000, 800, 600, 400, 300, 200, 150, 100, 80, 50, 30 , and $0 \mu \mathrm{mol} \mathrm{m} \mathrm{m}^{-2}$. Response curves were modeled using a nonrectangular hyperbola according to Prioul and Chartier (1977). The light-saturated photosynthetic rate $\left(A_{\max }\right)$, apparent quantum efficiency $(\Phi)$, and light compensation point $\left(L_{\mathrm{CP}}\right)$ were determined by fitting the measured data to the model function.

The response of $A$ to changing $\mathrm{CO}_{2}$ was measured at $400 \mu \mathrm{mol} \mathrm{mol}{ }^{-1}$, which was decreased to $300,200,150,100$, and $50 \mu \mathrm{mol} \mathrm{mol}{ }^{-1}$, then returned to 400 , and subsequently increased to $500,600,800,1000$, and $1200 \mu^{m o l ~ m o l}{ }^{-1}$ under saturating irradiance $\left(1000 \mu \mathrm{mol} \mathrm{m} \mathrm{m}^{-2} \mathrm{PPFD}\right)$. The photosynthesis curve plotted against the intercellular $\mathrm{CO}_{2}$ concentration $\left(C_{\mathrm{i}}\right)$ was analyzed to estimate the $\mathrm{CO}_{2}$ compensation point $(\Gamma)$, the maximum rate of $\mathrm{RuBP}$ carboxylation $\left(V_{\mathrm{cmax}}\right)$, and maximum rate of electron transport driving the regeneration of RuBP $\left(J_{\max }\right)$ according to Long and Bernacchi (2003). The normalized leaf areas were used when calculating these parameters. The mesophyll conductance $\left(g_{\mathrm{m}}\right)$ was estimated based on the hypothesis that $g_{\mathrm{m}}$ reduces the curvature of the Rubiscolimited portion of an $A / C_{\mathrm{i}}$ response curve (Ethier and Livingston 2004; Duan et al. 2009). $A / C_{i}$ curves were fitted with a nonrectangular hyperbolic version of the biochemical model of $\mathrm{C}_{3}$ leaf photosynthesis by Farquhar et al. (1980).

$A=\min \left\{P_{\mathrm{c}}, P_{\mathrm{r}}\right\}-R_{\mathrm{d}}$

$P_{\mathrm{c}}=\frac{-b \pm \sqrt{b^{2}-4 a c}}{2 a}$

$a=-1 / g_{\mathrm{m}}$

$b=\left(V_{\mathrm{cmax}}-R_{d}\right) / g_{\mathrm{m}}+C_{\mathrm{i}}+K_{\mathrm{c}}\left(1+O / K_{\mathrm{o}}\right)$

$c=R_{\mathrm{d}}\left(V_{\mathrm{cmax}}\left(C_{\mathrm{i}}+K_{\mathrm{c}}\left(1+O / K_{\mathrm{o}}\right)\right)\right)-V_{\mathrm{cmax}}\left(C_{\mathrm{i}}-\Gamma^{*}\right)$

$P_{\mathrm{r}}=\frac{-b \pm \sqrt{b^{2}-4 a c}}{2 a}$

$a=-1 / g_{\mathrm{m}}$

$b=\left(J / 4-R_{d}\right) / g_{\mathrm{m}}+C_{\mathrm{i}}+2 \Gamma^{*}$

$c=R_{\mathrm{d}}\left(C_{\mathrm{i}}+2 \Gamma^{*}\right)-J / 4\left(C_{\mathrm{i}}-\Gamma^{*}\right)$

where $P_{\mathrm{c}}$ and $P_{\mathrm{r}}$ are the RuBP-saturated and RuBP-limited net $\mathrm{CO}_{2}$ assimilation rates, respectively, $J$ is the photochemical electron transport rate under RuBP-limited conditions, $R_{\mathrm{d}}$ is the mitochondrial respiration under light conditions, $\Gamma^{*}$ is the $\mathrm{CO}_{2}$ compensation point in the absence of mitochondrial respiration under light conditions, $K_{\mathrm{c}}$ and $K_{\mathrm{o}}$ are the Michaelis-Menten constants for RuBP carboxylation and oxygenation, respectively, and $O$ is the oxygen concentration. In this study, for $K_{\mathrm{c}}(1+$ $O / K_{\mathrm{o}}$ ), a value of $736 \mu \mathrm{mol} \mathrm{mol}{ }^{-1}$ was used according to Duan et al. (2009), while $\Gamma^{*}$ was calculated according to Laisk (1977).

\subsection{Foliar carbon isotope composition $\left(\delta^{13} \mathrm{C}\right)$}

Current-year leaves were selected for the $\delta^{13} \mathrm{C}$ analysis. Samples were oven-dried at $70^{\circ} \mathrm{C}$ for $24 \mathrm{~h}$ and homogenized by grinding in a ball mill. The $\delta^{13} \mathrm{C}$ in the combusted samples 
was measured using a mass spectrometer (Finnegan MAT Delta-E) following Li et al. (2004). The overall precision of the $\delta$ values was higher than $0.1 \%$, as determined from repeated samples.

\subsection{Chlorophyll pigment measurements}

Current-year leaves $(0.2 \mathrm{~g})$ were extracted in $80 \%$ chilled acetone $(v / v)$ after weighing. The absorbance of extracts was measured using a Unicam UV-330 spectrophotometer (Unicam, Cambridge, UK) at 470, 646, and $663 \mathrm{~nm}$. The chlorophyll concentrations were calculated from equations derived by Porra et al. (1989). The total chlorophyll content (Tchl) was the sum of chlorophyll a (Chl $a$ ) and chlorophyll b $(\mathrm{Chl} b)$.

\subsection{Nutrient contents}

Leaves were dried at $70^{\circ} \mathrm{C}$ for $48 \mathrm{~h}$, and soils were air-dried at room temperature and then ground. Element contents were determined following the methods of Graefe et al. (2010). The C and $\mathrm{N}$ contents were determined using a $\mathrm{C} / \mathrm{N}$ elemental analyzer (Vario EL 3, Fa. Elementar, Hanau, Germany). The phosphorus contents were analyzed by yellow dyeing with $\mathrm{NH}_{4} \mathrm{VO}_{3}$ and $\left(\mathrm{NH}_{4}\right)_{6} \mathrm{Mo}_{7} \mathrm{O}_{24}$ and subsequent photometric measurement after digestion with $65 \% \mathrm{HNO}_{3}$ at $195^{\circ} \mathrm{C} . \mathrm{K}, \mathrm{Ca}, \mathrm{Mg}, \mathrm{Fe}, \mathrm{Mn}$, $\mathrm{Zn}$, and $\mathrm{Al}$ contents were determined by atomic absorption spectroscopy (GBC932, GBC, Melbourne, Australian) after $\mathrm{HNO}_{3}$ digestion. The photosynthetic nitrogen use efficiency (PNUE) is expressed as the ratio of $A_{\max }$ to the nitrogen content per unit of leaf area. Similarly, the photosynthetic phosphorus use efficiency (PPUE) is expressed as the ratio of $A_{\max }$ to the phosphorus content per unit of leaf area.

\subsection{Statistical analysis}

Eight biological replicates were used for each treatment. From the previous analysis, we found that there was no difference between the two populations. Therefore, in this study, the results of the two populations were merged, and the effect of population was ignored. All data were analyzed using SPSS 16.0 software (SPSS Inc., Chicago, IL, USA). Two-way analyses of variance (ANOVAs) were used to test the overall effects of planting density, soils, and their interaction. All data were checked for normality and the homogeneity of variances and were log-transformed to correct deviations from these assumptions when needed. Post hoc comparisons were tested using Tukey's test at a significance level of $\alpha=0.05$.

\section{Results}

As shown in Table 1, the contents of organic carbon (C), N, and $\mathrm{P}$ were lower in soils that were continuously planted with Chinese fir than in soils that were first planted with Chinese fir. The height growth; stem basal expansion; and root, stem, leaf, and total biomass were smaller under the high planting density than under the low planting density in both types of soil (Table 2). Among of the four treatments, all of the growth parameters were smallest in soils that were continuously planted with Chinese fir under a high planting density. Interestingly, under the high planting density, the ratio of aboveground mass to belowground mass was larger in soils that were first planted with Chinese fir but was smaller in soils from continuous Chinese fir plantations.

The values of $A$ and $g_{s}$ were smaller under the high planting density in both types of soil (Table 3 ). In soils that were continuously planted with Chinese fir, the $\mathrm{Chl} a, \mathrm{Chl} b$, and total chlorophyll contents were significant higher, but the ratio of $\mathrm{Chl} a / \mathrm{Chl} b$ was lower under the high planting density than under the low planting density. However, in soils that were first planted with Chinese fir, the chlorophyll pigment contents were not different between planting densities. Additionally, the values of $C_{i}$ and leaf $\delta^{13} \mathrm{C}$ had no significant differences under different planting densities or different soils.

Table 2 The growth parameters of $C$. lanceolata as affected by a high planting density under soils that were first (control) and continuously planted with Chinese fir (rotation)

\begin{tabular}{lllllllll}
\hline Soils & $\begin{array}{l}\text { Planting } \\
\text { density }\end{array}$ & Height $(\mathrm{cm})$ & $\begin{array}{l}\text { Base stem } \\
\text { diameter }(\mathrm{mm})\end{array}$ & Root mass (g) & $\begin{array}{l}\text { Stem } \\
\text { mass }(\mathrm{g})\end{array}$ & Leaf mass (g) & $\begin{array}{l}\text { Total } \\
\text { mass (g) }\end{array}$ & $\begin{array}{l}\text { Aboveground/ } \\
\text { belowground ratio }\end{array}$ \\
\hline Control & Low & $59.52 \pm 0.72 \mathrm{~d}$ & $10.52 \pm 0.12 \mathrm{c}$ & $29.48 \pm 0.46 \mathrm{~b}$ & $20.78 \pm 0.34 \mathrm{~d}$ & $35.82 \pm 1.18 \mathrm{c}$ & $84.21 \pm 1.73 \mathrm{c}$ & $1.92 \pm 0.05 \mathrm{~b}$ \\
& High & $47.17 \pm 0.93 \mathrm{~b}$ & $7.50 \pm 0.13 \mathrm{~b}$ & $9.46 \pm 0.41 \mathrm{a}$ & $7.23 \pm 0.30 \mathrm{~b}$ & $13.05 \pm 0.32 \mathrm{~b}$ & $29.74 \pm 0.68 \mathrm{~b}$ & $2.18 \pm 0.10 \mathrm{c}$ \\
Rotation & Low & $55.51 \pm 0.73 \mathrm{c}$ & $10.21 \pm 0.12 \mathrm{c}$ & $28.24 \pm 0.36 \mathrm{~b}$ & $18.01 \pm 0.36 \mathrm{c}$ & $33.16 \pm 1.23 \mathrm{c}$ & $81.28 \pm 0.93 \mathrm{c}$ & $1.82 \pm 0.06 \mathrm{~b}$ \\
& High & $37.79 \pm 0.69 \mathrm{a}$ & $6.95 \pm 0.12 \mathrm{a}$ & $9.16 \pm 0.32 \mathrm{a}$ & $4.49 \pm 0.13 \mathrm{a}$ & $8.62 \pm 0.37 \mathrm{a}$ & $22.27 \pm 0.68 \mathrm{a}$ & $1.44 \pm 0.03 \mathrm{a}$ \\
& $P_{\mathrm{S}}$ & 0.000 & 0.003 & 0.057 & 0.000 & 0.000 & 0.000 & 0.000 \\
& $P_{\mathrm{D}}$ & 0.000 & 0.000 & 0.000 & 0.000 & 0.000 & 0.000 & 0.329 \\
& $P_{\mathrm{S} \times \mathrm{D}}$ & 0.396 & 0.402 & 0.241 & 0.956 & 0.324 & 0.045 & 0.000 \\
\hline
\end{tabular}

Each value is the mean $\pm \mathrm{SE}(n=8)$. Within a column, values followed by different letters are significantly different at $P<0.05$ according to Tukey's test $P_{S}$ soil effect, $P_{D}$ density effect, $P_{S \times D}$ soil and density interaction effect 
From the analysis of $A-C_{i}$ and $A$-light curves, we knew that the values of $\Gamma, L_{\mathrm{CB}}$ and $A_{\max }$ were significant lower, and the values of $V_{\text {cmax }}$ and $J_{\max }$ were similar, irrespective of planting density and soil type (Table 4). Additionally, under the high planting density, the value of $g_{\mathrm{m}}$ was significant lower in soils that were continuously planted with Chinese fir, whereas $\Phi$ was significantly lower in soils that were first planted with Chinese fir.

As shown in Table 5, the $\mathrm{Fe}, \mathrm{Zn}$, and $\mathrm{Al}$ contents were higher under the high planting density in both types of soil. Especially under the high planting density, $\mathrm{P}$ and $\mathrm{Mg}$ contents in leaves were significantly lower and the N/P ratio was higher in soils that were continuously planted with Chinese fir, but there was less of a difference in soils that were first planted with Chinese fir. However, the $\mathrm{C}, \mathrm{N}$, and $\mathrm{K}$ contents and the $\mathrm{C} / \mathrm{N}$ ratio in the leaves were less different among of treatments. In addition, the values of PNUE and PPUE were smaller under the high planting density in both types of soil, and they were smallest in soils that were continuously planted with Chinese fir (Table 4).

\section{Discussion}

In fast-growing plants, a high planting density can decrease photosynthesis and biomass through self-shading, competition for nutrients or water, and the excretion of allelochemicals in soils (He and Bazzaz 2003). Because plants have similar resource needs, intraspecific competition is stronger in nutrient-deficient soils, e.g., soils that were continuously planted with Chinese fir, as in this study. On the other hand, a high planting density may increase the intensity of the competition. In trees, the increase in the chlorophyll pigment and the decrease of the $\mathrm{Chl} a / \mathrm{Chl} b$ ratio are characteristics of the shaded leaves (Sarijeva et al. 2007; Chaves et al. 2008; Lichtenthaler et al. 2013). In this study, the high light compensation point and chlorophyll pigment content and a low $\mathrm{Chl} a / \mathrm{Chl} b$ ratio clearly suggested that there were light limitations for plant growth under a high planting density. Additionally, we found a low photosynthetic level at high densities, with nevertheless a relatively high $C_{i}$, suggesting that the stomatal conductance was not the main limitation on photosynthesis (Tuzet et al. 2003). Relative to the stomatal conductance, the mesophyll conductance was more sensitive to changes in the surroundings, such as shading (Niinemets et al. 2006; Warren et al. 2007; Flexas et al. 2007, 2008) and drought (Duan et al. 2009). Leaves of trees in a higher planting density usually suffer from lower light irradiance from the shading of among branches (Warren et al. 2001). In this study, the lower $g_{\mathrm{m}}$ in the high planting density was consistent with that found in previous studies (Piel et al. 2002; Niinemets et al. 2006; Flexas et al. 2007; Warren et al. 2007). In addition to $g_{\mathrm{m}}$, the decrease in the photosynthetic rate was usually caused by 


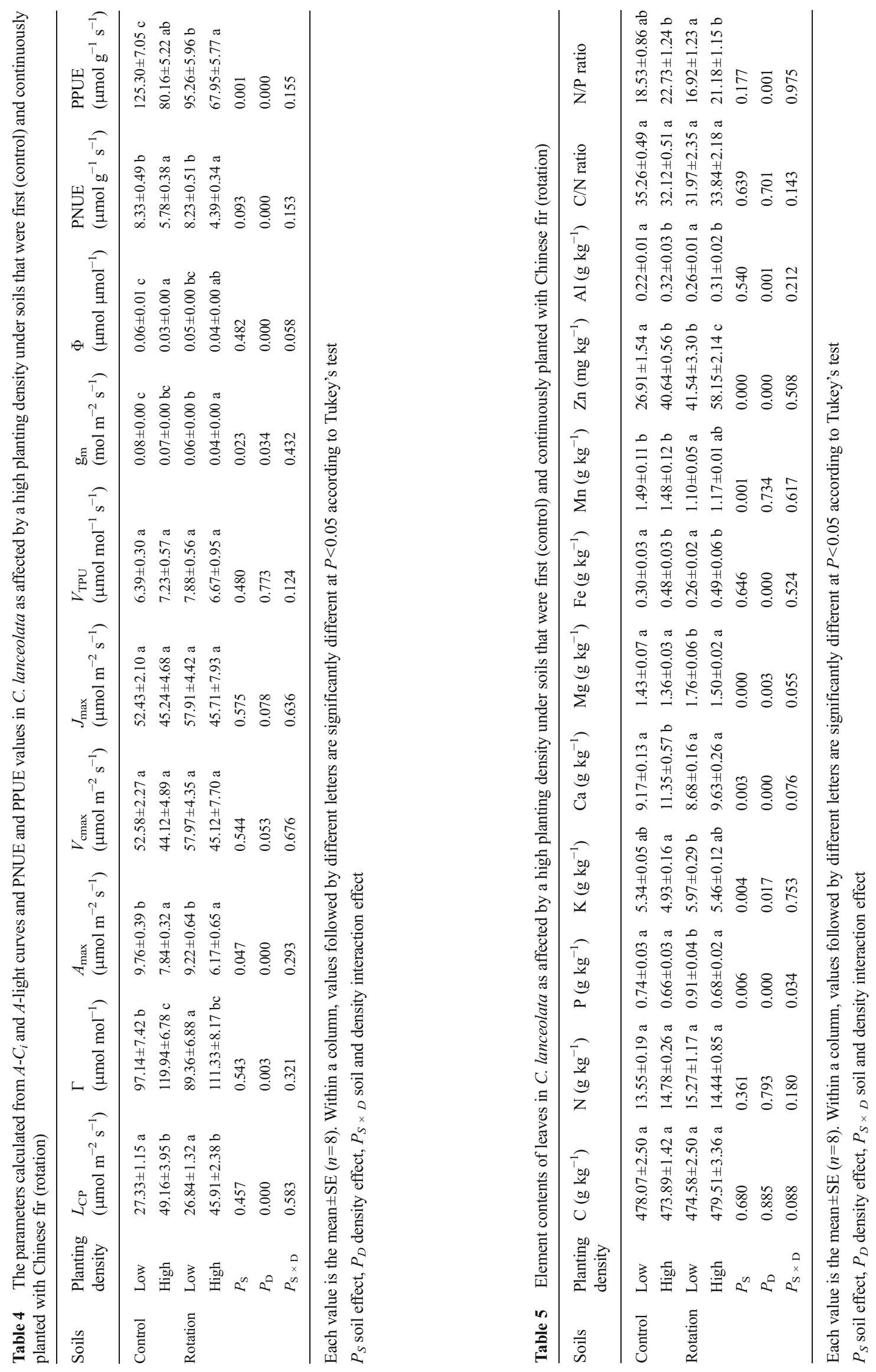


the limitation of Rubisco carboxylation and RuBP regeneration and further affected the activity of Rubisco and other enzymes involved in the Calvin cycle (Long and Bernacchi 2003 ); the results of $V_{\text {cmax }}$ and $J_{\max }$ in this study also supported this conclusion. Therefore, $g_{\mathrm{m}}$ and biochemical metabolism traits $\left(V_{\mathrm{cmax}}\right.$ and $\left.J_{\max }\right)$ in $C$. lanceolata collectively explained the low photosynthetic rate under the high planting density.

At the global scale, the photosynthetic capacity and nutrients in leaves are the core physiological traits (Wright et al. 2004). $\mathrm{N}$ and $\mathrm{P}$ are generally considered the nutrients that most strongly affect photosynthesis in leaves (Boyce et al. 2006). Numerous studies have reported that photosynthesis is determined by the $\mathrm{N}$ and $\mathrm{P}$ concentrations or the $\mathrm{N} / \mathrm{P}$ ratio in leaves (Loustau et al. 1999; Utriainen and Holopainen 2001; Boyce et al. 2006; Cernusak et al. 2010; Garrish et al. 2010). The foliar N/P ratio above a certain threshold indicates $\mathrm{P}$ limitations to biomass production, and below a certain threshold, it indicates $\mathrm{N}$ limitation. In this study, the high planting density did not cause a significant difference in the $\mathrm{N}$ content or the $\mathrm{C} / \mathrm{N}$ ratio, but it did cause a significantly low $\mathrm{P}$ content and a high N/P ratio in the leaves, suggesting that $\mathrm{P}$ was the limiting factor of photosynthesis. These limitations were stronger in soils that were continuously planted with Chinese fir.

The rates of photosynthesis per unit of leaf $\mathrm{N}$ and $\mathrm{P}$, termed the instantaneous photosynthetic $\mathrm{N}$ and $\mathrm{P}$ use efficiency (PNUE and PPUE), have been considered important plant functional traits used to characterize species in relation to their leaf economics and physiology (Hikosaka 2004; Duan et al. 2008; Hidaka and Kitayama 2009). In this study, the low PNUE and PPUE suggest that there were low photosynthetic $\mathrm{N}$ and $\mathrm{P}$ utilization efficiencies under the high planting density. Physiologically, a low PNUE may be caused by lower N partitioning into Rubisco versus higher $\mathrm{N}$ partitioning into cell walls (Hikosaka 2004; Takashima et al. 2004; Hidaka and Kitayama 2009). A low PPUE can be explained by an unbalanced allocation of $P$ between cells containing $P$ biochemical compounds, e.g., foliar P fractions (Hidaka and Kitayama 2011, 2013; Veneklaas et al. 2012). Therefore, a high planting density may change the allocation and balance of $\mathrm{N}$ and $\mathrm{P}$ in plant cells.

Magnesium is an integral component of the chlorophyll molecule and the enzymatic processes associated with photosynthesis and respiration (Barker and Pilbeam 2007). Magnesium is also an integral component of DNA and RNA, and the role that this ion plays in many polynucleotides cannot be replaced by other cations (Porschke 1995). Therefore, a decrease in the $\mathrm{Mg}$ content in leaves may relate to the decrease in photosynthetic activity under a high planting density. In addition, it is possible that the increase in the contents of $\mathrm{Zn}$ and $\mathrm{Fe}$ can suppress the accumulation of $\mathrm{Mg}$ in leaves (Kaya et al. 2001). Therefore, the high Fe and Zn contents in the leaves may lead to a further decrease in the $\mathrm{Mg}$ content in soils that were continuously planted with Chinese fir. In southern China, the soils that were planted with C. lanceolata were acidic. Traditionally, acidic red soils are always lacking in $\mathrm{P}, \mathrm{Ca}, \mathrm{K}$, and $\mathrm{Mg}$ but are enriched in $\mathrm{Fe}, \mathrm{Zn}$, and $\mathrm{Al}$ (Sun et al. 2000; Zhao et al. 2007; Cheng et al. 2009). Therefore, the higher $\mathrm{Fe}, \mathrm{Zn}$, and $\mathrm{Al}$ contents in the leaves and the lower $\mathrm{P}$ and $\mathrm{Mg}$ contents under the high planting density may due to the initial conditions of the soil nutrients. It is proposed that continuous planting with $C$. lanceolata on the same site with the same nutrient resource demands, especially of $\mathrm{P}$ and $\mathrm{Mg}$, can limit plant growth and productivity.

The value of $\delta{ }^{13} \mathrm{C}$ has been used as an indicator that reflects the long-term water use efficiency of plants (Warren et al. 2001; Duan et al. 2009; Dong et al. 2015). Our previous study found that $C$. lanceolata saplings were sensitive to water use efficiency (estimated from foliage $\delta^{13} \mathrm{C}$ ) when its partial lateral branches were shaded in a field study (Dong et al. 2015). However, in this study, foliage $\delta^{13} \mathrm{C}$ values changed less, suggesting that the long-term water use efficiency was not greatly affected by a high planting density. The results reflected a proportionate change between $A$ and $g_{\mathrm{s}}$ because leaf $\delta^{13} \mathrm{C}$ was related to the balance between them (Farquhar et al. 1989; Warren et al. 2001). On the other hand, water was probably not a limiting factor because there was a sufficient water supply in this study. Therefore, the decline of photosynthesis, as well as $g_{\mathrm{m}}$, was not related to water competition, but rather might have been related to light and (or) nutrient stress in a high planting density.

We have to indicate that in this study, the report of the productive yield (biomass accumulation) used the means of the individual seedlings, and the measurement of photosynthesis occurred at the leaf level. Therefore, the results may differ from biomass calculations at the whole boxes level and photosynthesis measurement at the canopy level. There were more seedlings in the high planting density boxes, and although the means of the individual biomass were lower, the total biomass of whole stand was higher than at the low planting density. However, it is difficult to estimate the productivity of the whole stand. In addition, in this study, 1-year-old seedlings were used. Photosynthesis, water utilization, and nutrient allocation patterns may differ between young and adult trees. Mature trees have larger canopies, complex structures, and similar nutrient requirements. We believe that in addition to differences between species, adult trees generally have higher photosynthetic capacities and stomatal conductances than saplings (Thomas and Winner 2002; Van Wittenberghe et al. 2012). Therefore, adult trees may show stronger competition for resources than saplings in a typical forest situation.

In conclusion, individually, $C$. lanceolata had low plant growth, biomass accumulation, and photosynthesis under a high planting density, and these values were lower in soils that were continuously planted with Chinese fir. The lower photosynthesis at the leaf level caused by a high planting density 
was driven by lower amounts of $\mathrm{P}$ and $\mathrm{Mg}$ in the leaves, a lower foliar N/P ratio, and limitations of Rubisco carboxylation and RuBP regeneration and mesophyll conductance. The results from this study suggest that the main limitations to growth and photosynthesis in young $C$. lanceolata under a high planting density are light and nutrients, especially $\mathrm{P}$ and $\mathrm{Mg}$.

Acknowledgments This work was supported by the National Key Basic Research Program of China (No. 2012CB416901) and Young Talent Team Program of the Institute of Mountain Hazards and Environment (SDSQB-2012-02).

\section{Conflict of interest None declared.}

Contribution of co-authors Dr Tingfa Dong did some measurements and statistical analysis (40\%) and some of the manuscript writing (20\%). Ms Yunxiang Zhang did much of the field work $(50 \%)$ and the measurements and statistical analysis $(20 \%)$. Dr Yuanbin Zhang did much of the field work (50\%). Dr Sheng Zhang had the initial research idea and acquired the funding for the project which was done in his laboratory; he also did some measurements and statistical analysis (40\%) and the manuscript writing $(80 \%)$ of the paper during initial submission.

\section{References}

Anten NPR, Hirose T (2001) Limitations on photosynthesis of competing individuals in stands and the consequences for canopy structure. Oecologia 129:186-196

Barker AV, Pilbeam DJ (2007) Handbook of plant nutrition. Taylor and Francis Group, Boca Raton London, New York

Bi J, Blanco JA, Seely B, Kimmins JP, Ding Y, Welham C (2007) Yield decline in Chinese-fir plantations: a simulation investigation with implications for model complexity. Can J For Res 37:1615-1630

Boyce RL, Larson JR, Sanford RL (2006) Phosphorus and nitrogen limitations to photosynthesis in Rocky Mountain bristlecone pine (Pinas aristata) in Colorado. Tree Physiol 26:1477-1486

Cernusak LA, Winter K, Turner BL (2010) Leaf nitrogen to phosphorus ratios of tropical trees: experimental assessment of physiological and environmental controls. New Phytol 185:770-779

Chaves ARM, Ten-Caten A, Pinheiro HA, Ribeiro A, DaMatta FM (2008) Seasonal changes in photoprotective mechanisms of leaves from shaded and unshaded field-grown coffee (Coffea arabica L.) trees. Trees-Struct Funct 22:351-361

Chen LC, Wang SL (2013) Allelopathic behaviour of Chinese fir from plantations of different ages. Forestry 86:225-230

Chen LH, Han Y, Jiang H, Korpelainen H, Li CY (2011) Nitrogen nutrient status induces sexual differences in responses to cadmium in Populus yunnanensis. J Exp Bot 62:5037-5050

Chen J, Duan BL, Wang ML, Korpelainen H, Li CY (2014) Intra- and inter-sexual competition of Populus cathayana under different watering regimes. Funct Ecol 28:124-136

Cheng FX, Cao GQ, Wang XR, Zhao J, Yan XL, Liao H (2009) Isolation and application of effective nitrogen fixation rhizobial strains on low-phosphorus acid soils in South China. Chin Sci Bull $54: 412-420$

Ding Y, Cheng J (1995) Effect of continuous plantation of Chinese fir on soil fertility. Pedosphere 51:47-66

Dong TF, Li JY, Zhang YB, Korpelainen H, Niinemets Ü, Li CY (2015) Partial shading of lateral branches affects growth, and foliage nitrogen-and water-use efficiencies in the conifer Cunninghamia lanceolata growing in a warm monsoon climate. Tree Physiol 35: 632-643

Dorman M, Perevolotsky A, Sarris D, Svoray T (2015) The effect of rainfall and competition intensity on forest response to drought: lessons learned from a dry extreme. Oecologia 177:1025-1038

Duan BL, Xuan ZY, Zhang XL, Korpelainen H, Li CY (2008) Interactions between drought, ABA application and supplemental UV-B in Populus yunnanensis. Physiol Plant 134:257-269

Duan BL, Li Y, Zhang XL, Korpelainen H, Li CY (2009) Water deficit affects mesophyll limitation of leaves more strongly in sun than in shade in two contrasting Picea asperata populations. Tree Physiol 29:1551-1561

Dybzinski R, Farrior CE, Ollinger S, Pacala SW (2013) Interspecific vs intraspecific patterns in leaf nitrogen of forest trees across nitrogen availability gradients. New Phytol 200:112-121

Ethier GH, Livingston NJ (2004) On the need to incorporate sensitivity to $\mathrm{CO}_{2}$ transfer conductance into the Farquhar-von Caemmerer-Berry leaf photosynthesis model. Plant Cell Environ 27:137-153

FAO 2010 Global forest resources assessment 2010. Main report. FAO Forestry Paper: 163, Rome, Italy

Farquhar GD, Hubick KT, Condon AG, Richards RA (1989) Carbon isotope fractionation and plant water-use efficiency. In: Ehleringer JR, Nagy KA (eds) Rundel PW. Stable isotopes in ecological research, Springer New York, pp 21-40

Flexas J, Diaz-Espejo A, GalmÉS J, Kaldenhoff R, Medrano H, RibasCarbo M (2007) Rapid variations of mesophyll conductance in response to changes in $\mathrm{CO}_{2}$ concentration around leaves. Plant Cell Environ 30:1284-1298

Flexas J, Ribas-CarbÓ M, Diaz-Espejo A, GalmÉS J, Medrano H (2008) Mesophyll conductance to $\mathrm{CO}_{2}$ : current knowledge and future prospects. Plant Cell Environ 31:602-621

Garrish V, Cernusak LA, Winter K, Turner BL (2010) Nitrogen to phosphorus ratio of plant biomass versus soil solution in a tropical pioneer tree, Ficus insipida. J Exp Bot 61:3735-3748

Graefe S, Hertel D, Leuschner C (2010) N, P and K limitation of fine root growth along an elevation transect in tropical mountain forests. Acta Oecol 36:537-542

He JS, Bazzaz FA (2003) Density-dependent responses of reproductive allocation to elevated atmospheric $\mathrm{CO}_{2}$ in Phytolacca americana. New Phytol 157:229-239

Hidaka A, Kitayama K (2009) Divergent patterns of photosynthetic phosphorus-use efficiency versus nitrogen-use efficiency of tree leaves along nutrient-availability gradients. J Ecol 97:984-991

Hidaka A, Kitayama K (2011) Allocation of foliar phosphorus fractions and leaf traits of tropical tree species in response to decreased soil phosphorus availability on Mount Kinabalu, Borneo. J Ecol 99:849 857

Hidaka A, Kitayama K (2013) Relationship between photosynthetic phosphorus-use efficiency and foliar phosphorus fractions in tropical tree species. Ecol Evol 3:4872-4880

Hikosaka K (2004) Interspecific difference in the photosynthesis-nitrogen relationship: patterns, physiological causes, and ecological importance. J Plant Res 117:481-494

Kaya C, Burton MAS, Higgs DEB (2001) Responses of tomato CVs growth to fruit-harvest stage under zinc stress in glasshouse conditions. J Plant Nutr 24:369-382

Laisk AK (1977) Kinetics of photosynthesis and photorespiration in $\mathrm{C}_{3}$ plants. Nauka, Moscow, Russia

Li CY, Liu SR, Berninger F (2004) Picea seedlings show apparent acclimation to drought with increasing altitude in the eastern Himalaya. Trees-Struct Funct 18:277-283

Lichtenthaler HK, Babani F, Navrátil M, Buschmann C (2013) Chlorophyll fluorescence kinetics, photosynthetic activity, and pigment composition of blue-shade and half-shade leaves as compared to sun and shade leaves of different trees. Photosynth Res 117:355-366 
Long SP, Bernacchi CJ (2003) Gas exchange measurements, what can they tell us about the underlying limitations to photosynthesis? Procedures and sources of error. J Exp Bot 54:2393-2401

Loustau D, Ben Brahim M, Gaudillere JP, Dreyer E (1999) Photosynthetic responses to phosphorus nutrition in two-year-old maritime pine seedlings. Tree Physiol 19:707-715

Mediavilla S, Escudero A, Heilmeier H (2001) Internal leaf anatomy and photosynthetic resource-use efficiency: interspecific and intraspecific comparisons. Tree Physiol 21:251-259

Niinemets Ü, Cescatti A, Rodeghiero M, Tosens T (2006) Complex adjustments of photosynthetic potentials and internal diffusion conductance to current and previous light availabilities and leaf age in Mediterranean evergreen species Quercus ilex. Plant Cell Environ 29:1159-1178

Piel C, Frak E, Le Roux X, Genty B (2002) Effect of local irradiance on $\mathrm{CO}_{2}$ transfer conductance of mesophyll in walnut. J Exp Bot 53: 2423-2430

Porra RJ, Thompson WA, Kriedmann PE (1989) Determination of accurate extinction coefficients and simultaneous equations for assaying chlorophylls $\mathrm{a}$ and $\mathrm{b}$ extracted with four different solvents: verification of the concentration of chlorophyll standards by atomic absorption spectroscopy. Biochim Biophys Acta 975:384-394

Porschke, D. 1995 Modes and dynamics of $\mathrm{Mg}^{2+}$-polynucleotide interactions. In: J.A. Cowan, (Ed). The biological chemistry of magnesium. New York: VCH Publishers, Inc, pp. 85-110.

Prioul JL, Chartier P (1977) Partitioning of transfer and carboxylation components of intercellular resistance to photosynthetic $\mathrm{CO}_{2}$ fixation: a critical analysis of the method used. Ann Bot 41:789-800

Sarijeva G, Knapp M, Lichtenthater HK (2007) Differences in photosynthetic activity, chlorophyll and carotenoid levels, and in chlorophyll fluorescence parameters in green sun and shade leaves of Ginkgo and Fagus. J Plant Physiol 164:950-955

Sun B, Poss R, Moreau R, Aventurier A, Fallavier P (2000) Effect of slaked lime and gypsum on acidity alleviation and nutrient leaching in an acid soil from Southern China. Nutr Cycl Agroecosys 57:215223

Takashima T, Hikosaka K, Hirose T (2004) Photosynthesis or persistence: nitrogen allocation in leaves of evergreen and deciduous Quercus species. Plant Cell Environ 27:1047-1054

Thomas SC, Winner WE (2002) Photosynthetic differences between saplings and adult trees: an integration of field results by meta-analysis. Tree Physiol 22:117-127
Tian DL, Xiang WH, Chen XY, Yan WD, Fang X, Kang WX, Dan XW, Peng CH, Peng YY (2011) A long-term evaluation of biomass production in first and second rotations of Chinese fir plantations at the same site. Forestry $84: 411-418$

Tuzet A, Perrier A, Leuning R (2003) A coupled model of stomatal conductance, photosynthesis and transpiration. Plant Cell and Environ 26:1097-1116

Utriainen J, Holopainen T (2001) Influence of nitrogen and phosphorus availability and ozone stress on Norway spruce seedlings. Tree Physiol 21:447-456

Van Wittenberghe S, Adriaenssens S, Staelens J, Verheyen K, Samson R (2012) Variability of stomatal conductance, leaf anatomy, and seasonal leaf wettability of young and adult European beech leaves along a vertical canopy gradient. Trees-Struct Funct 26:1427-1438

Veneklaas EJ, Lambers H, Bragg J, Finnegan PM, Lovelock CE, Plaxton WC, Price CA, Scheible WR, Shane MW, White PJ, Raven JA (2012) Opportunities for improving phosphorus-use efficiency in crop plants. New Phytol 195:306-320

Wang LW, Showalter AM, Ungar IA (2005) Effects of intraspecific competition on growth and photosynthesis of Atriplex prostrata. Aquat Bot 83:187-192

Wang SL, Zhang WD, Sanchez F (2010) Relating net primary productivity to soil organic matter decomposition rates in pure and mixed Chinese fir plantations. Plant Soil 334:501-510

Warren CR, McGrath JF, Adams MA (2001) Water availability and carbon isotope discrimination in conifers. Oecologia 127:476-486

Warren C, Löw M, Matyssek R, Tausz M (2007) Internal conductance to $\mathrm{CO}_{2}$ transfer of adult Fagus sylvatica: variation between sun and shade leaves and due to free-air ozone fumigation. Environ Exp Bot 59:130-138

Wright IJ, Reich PB, Westoby M, Ackerly DD, Baruch Z, Bongers F et al (2004) The world-wide leaf economics spectrum. Nature 428:821827

Zhang WD, Wang SL (2012) Effects of $\mathrm{NH}_{4}{ }^{+}$and $\mathrm{NO}_{3}{ }^{-}$on litter and soil organic carbon decomposition in a Chinese fir plantation forest in South China. Soil Biol Biochem 47:116-122

Zhang X, Kirschbaum MUF, Hou Z, Guo Z (2004) Carbon stock changes in successive rotations of Chinese fir (Cunninghamia lanceolata (lamb) hook) plantations. For Ecol Manage 202:131-147

Zhao JQ, Michalk DL, Wen YF, Kemp DR, Du GZ, Nicol H (2007) Effect of phosphorus, potassium and lime application on pasture in acid soil in Yunnan Province, China. New Zeal J Agr Res 50:523535 